\title{
Influence of an increased content of pea and yellow lupin protein in the diet of pigs on meat quality
}

\author{
Aleksandra Cebulska ${ }^{1 *}\left(\mathbb{0}\right.$, Hanna Jankowiak ${ }^{1}$, Eva Weisbauerová ${ }^{2}$ and Pavel Nevrkla ${ }^{3}$
}

\begin{abstract}
Background: The aim of the study was to test the effect of replacing soya beans with pea and yellow lupin seeds in the diet of pigs on meat quality. The meat for the tests was obtained from 60 fattening crossbred pigs $F_{1}$ (Polish Large White $\times$ Polish Landrace) $\times$ F1 (Pietrain $\times$ Duroc). The animals belonged to three feeding groups depending on the feed used with the total share of soybeans and its reduction. Water holding capacity, colour, and tenderness were measured and visual and tactile evaluation (colour, marbling and firmness) was performed for meat samples collected from the longissimus lumborum muscle. The chemical composition of the meat and the content of minerals were determined. The content of amino acids, fatty acids and cholesterol was determined.

Results: There was no significant differences among the assessed physicochemical characteristics of the meat. The obtained meat was of good quality, regardless of the proportion of proteins from legumes in the diet of pigs. The results of the subjective evaluation of meat, its colour, and the content of muscle pigments were uniform in all food groups. Similarly, a uniform, high protein content was found in all tested groups (C-24.98\%; E1 - 24.82\%; E2-25.09\%) and the content of macro- and micronutrients in the tested meat was equivalent. The profile of fatty acids was not significantly affected by dietary treatment. Palmitoleic acid content was significantly higher $(P<0.05)$ in the E2 group compared to the E1 group (3.279\% compared to 2.844\%). The content of amino acids in meat samples was influenced by dietary treatment. Almost all the monitored essential amino acids (threonine, valine, leucine, phenylalanine and lysine) and some of nonessential amino acids' proportion was increased in the experimental groups (E1, E2).

Conclusion: Replacing soya bean protein in the pigs' diet with legume protein (peas and yellow lupin) did not adversely affect meat quality. This applies to both the physicochemical characteristics, the basic composition and the fatty acid profile. The meat of fattening pigs fed with the highest proportion of pea and lupin in the ration was characterized by more favourable proportion of essential amino acids.
\end{abstract}

Keywords: Fattening pigs, Nutrition, Soya bean extraction meal, Pea and yellow lupin, Meat quality traits

\footnotetext{
*Correspondence: cebulska@utp.edu.pl

${ }^{1}$ Department of Animal Breeding and Nutrition, Faculty of Animal

Breeding and Biology, UTP-University of Science and Technology

in Bydgoszcz, Mazowiecka 28, 85-084 Bydgoszcz, Poland

Full list of author information is available at the end of the article
}

\section{Background}

The quality of pork largely depends on the breed, but also on environmental factors such as nutrition, raising conditions and pre-slaughter handling procedures. Nutrition is one of the most significant of the environmental factors [1]. The use of certain feeds in the feeding of fattening pigs may significantly affect the physicochemical characteristics and the content of certain nutrients [2]. This also original author(s) and the source, provide a link to the Creative Commons licence, and indicate if changes were made. The images or other third party material in this article are included in the article's Creative Commons licence, unless indicated otherwise in a credit line to the material. If material is not included in the article's Creative Commons licence and your intended use is not permitted by statutory regulation or exceeds the permitted use, you will need to obtain permission directly from the copyright holder. To view a copy of this licence, visit http://creativecommons.org/licenses/by/4.0/. The Creative Commons Public Domain Dedication waiver (http://creativeco mmons.org/publicdomain/zero/1.0/) applies to the data made available in this article, unless otherwise stated in a credit line to the data. 
applies the content and origin of protein taken up by pigs in their feed [3].

The most commonly used protein component in complete feed mixtures for fattening pigs is soya bean extraction meal [4]. Soya bean is one of the plants that are improved by genetic modification to a great extent, which is beneficial from the point of view of cultivation and yields [5]. Unfortunately, it is related to consumers' fear of consuming meat and other animal products derived from the use of genetically modified organisms (GMOs). Concern about the impact of products made with the use of GMO feeds on the health of consumers causes a growing reluctance to use this type of feed [6]. In addition, the desire to become independent from the import of soya bean meal, which currently amounts to approximately 2 million tonnes per year in Poland, becomes increasingly pronounced in all Europe [7, 8]. This also results in a greater interest in feedstuffs containing protein sources other than soya beans. These are legumes, such as: lupins, peas or field beans, which, compared to other legumes, are characterised by a high protein content (over $40 \%$ in lupin seeds), high energy content and a low content of fibre and anti-nutritional compounds in pea seeds $[9,10]$.

An important aspect of the produced livestock is obtaining good quality meat. Many features are taken into account in the qualitative assessment. The best known are: color, drip loss, tenderness [11, 12] The results of numerous studies on the effect of feeding pigs with a complete feed mixture with a different proportion of legumes, indicate that it is possible to successfully replace soya bean extraction meal with pea or lupin seeds in the diet of pigs with no adverse impact on the quality of meat [13-16].

The aim of the study was to test the effect of replacing soya beans with pea and yellow lupin seeds in the diet of pigs on meat quality.

\section{Results}

The physicochemical characteristics of the meat were presented in Table 1. There was no significant differentiation of the assessed characteristics depending on the source of protein in the provided feed. The results obtained in all groups were equivalent. The acidity of the meat, both at the beginning $\left(\mathrm{pH}_{1}\right)$ and $48 \mathrm{~h}$ after slaughter $\left(\mathrm{pH}_{\mathrm{u}}\right)$, and parameters of the loss of juice from the meat was characteristic for good quality meat. In the case of tenderness, there weren't differences between the assessed groups. All the results concerning the physicochemical characteristics of the meat of fattening pigs fed with soya beans and hard-seeded legumes were typical for good quality meat.

The results of visual and tactile and instrumental evaluation of meat, colour and muscle pigments are presented
Table 1 Physicochemical characteristics of meat

\begin{tabular}{lrrrrr}
\hline \multicolumn{7}{c}{ Feeding group } \\
\cline { 2 - 6 } & \multicolumn{1}{c}{ C } & E1 & E2 & SEM & P< \\
\hline $\mathrm{pH}_{45}$ & 6.33 & 6.34 & 6.29 & 0.02 & 0.595 \\
$\mathrm{pH}_{\mathrm{u}}$ & 5.22 & 5.22 & 5.18 & 0.01 & 0.225 \\
WHC (\% of free water) & 17.42 & 16.81 & 18.07 & 0.42 & 0.466 \\
Thermal drip (\%) & 24.50 & 24.88 & 24.15 & 0.28 & 0.578 \\
WBSF (N) & 45.81 & 50.16 & 52.02 & 1.17 & 0.072 \\
Chemical composition of meat & & & & & \\
Water content (\%) & 72.42 & 72.45 & 72.18 & 0.09 & 0.461 \\
Total protein content (\%) & 24.98 & 24.82 & 25.09 & 0.08 & 0.439 \\
IMF (\%) & 1.43 & 1.21 & 1.39 & 0.10 & 0.625 \\
\hline
\end{tabular}

$\mathrm{pH}_{45} \mathrm{pH}$ at 45 min post slaughter, $\mathrm{pH}_{48 \mathrm{~h}} \mathrm{pH}$ at $48 \mathrm{~h}$ post slaughter, WHC Water holding capacity, WBSF Warner Braztler shear force (N Newton), IMF Intramuscular fat content

Table 2 Visual and tactile evaluation of meat, its colour and muscle pigments

\begin{tabular}{|c|c|c|c|c|c|}
\hline & \multicolumn{5}{|c|}{ Feeding group } \\
\hline & $\bar{C}$ & E1 & E2 & SEM & $P<$ \\
\hline \multicolumn{6}{|l|}{ Visual and tactile evaluation } \\
\hline Visual colour intensity (1-6 scale) & 2.8 & 3.1 & 3.1 & 0.07 & 0.137 \\
\hline Marbling (1-10 scale) & 1.6 & 1.6 & 1.5 & 0.07 & 0.523 \\
\hline Firmness (1-7 scale) & 4.2 & 4.1 & 4.3 & 0.05 & 0.351 \\
\hline \multicolumn{6}{|l|}{ Instrumental evaluation } \\
\hline \multicolumn{6}{|l|}{ Colour measurements } \\
\hline$L^{*}$ & 56.95 & 56.07 & 56.68 & 0.32 & 0.496 \\
\hline$a^{*}$ & 13.90 & 14.12 & 14.10 & 0.11 & 0.684 \\
\hline$b^{*}$ & 4.50 & 4.41 & 4.61 & 0.13 & 0.827 \\
\hline$C^{*}$ & 14.66 & 14.83 & 14.87 & 0.09 & 0.613 \\
\hline$h^{\circ}$ & 18.03 & 17.39 & 18.17 & 0.58 & 0.849 \\
\hline $\begin{array}{l}\text { Muscle pigments (micrograms of } \\
\text { hematin per } 1 \mathrm{~g} \text { of meat) }\end{array}$ & 35.26 & 35.43 & 35.19 & 1.06 & 0.996 \\
\hline
\end{tabular}

in Table 2. The results of the research in this area were equivalent in all feeding groups. The visual and tactile evaluation of the meat colour and the awarded points indicated that the test samples were characterised by an eye-pleasing, red-pink colour. This was confirmed by the instrumental evaluation of the colour brightness and the share of red and yellow colour in the meat. These parameters, in all analysed groups, reached the values typical for good quality meat.

Table 3 presents data concerning the content of macro- and microelements of the assessed meat samples. There were no statistically significant differences for the given characteristics between individual 
Table 3 Content of minerals in meat

\begin{tabular}{lccccc}
\hline $\begin{array}{l}\text { Minerals } \\
\left(\mathbf{m g}^{*} \mathbf{1 0 0} \mathbf{g}^{-\mathbf{1}} \mathbf{)}\right.\end{array}$ & \multicolumn{6}{l}{ Feeding group } \\
\cline { 2 - 6 } & $\mathbf{C}$ & \multicolumn{1}{l}{ E1 } & \multicolumn{1}{l}{ E2 } & SEM & $\boldsymbol{P}<$ \\
\hline $\mathrm{P}$ & 209.79 & 196.34 & 197.05 & 3.83 & 0.264 \\
$\mathrm{~K}$ & 393.59 & 392.63 & 389.28 & 4.24 & 0.914 \\
$\mathrm{Ca}$ & 7.52 & 6.3 & 7.11 & 0.21 & 0.064 \\
$\mathrm{Mg}$ & 27.73 & 27.41 & 27.55 & 0.98 & 0.994 \\
$\mathrm{Na}$ & 40.67 & 46.48 & 38.92 & 1.48 & 0.094 \\
$\mathrm{Fe}$ & 0.85 & 1.21 & 0.93 & 0.18 & 0.717 \\
$\mathrm{Zn}$ & 1.41 & 1.42 & 1.48 & 0.02 & 0.423 \\
$\mathrm{Cu}$ & 0.05 & 0.05 & 0.05 & 0.00 & 0.716 \\
$\mathrm{Mn}$ & 0.02 & 0.02 & 0.01 & 0.00 & 0.535 \\
\hline
\end{tabular}

feeding groups C, E1 and E2. However, it can be observed that among the macronutrients, phosphorus and potassium were the most frequent, while among the micronutrients, higher amounts of zinc and iron were recorded.

The content of fatty acids in meat samples is illustrated in Table 4 . The profile of fatty acids was not significantly affected by dietary treatment. Palmitoleic acid content was significantly $(P<0.05)$ higher in E2 group compared to E1 group (3.279 resp. $2.844 \mathrm{~g} / 100 \mathrm{~g}$ of total fatty acids). The proportion of $n-6 / n-3$ polyunsaturated fatty acids was not significantly affected by the diet. The level ranged from 6221 to 6812 . The atherogenic and thrombogenic indexes did not significantly differ among the groups.

The content of amino acids in meat samples was influenced by dietary treatment. The results are illustrated in Table 5. All monitored amino acids proportion was increased in experimental groups (E1 and E2), but not all significantly. Essential amino acid content, except methionine, was higher in E2 group compared to the $\mathrm{C}$ group $(P<0.05)$. There was not found significant difference in essential amino acid content between E1 and E2 group. The highest content was found for lysine (from 6.887 to $7.468 \mathrm{~g} / 100 \mathrm{~g}$ ). Nonessential amino acids were also affected by the diet with a different level of statistical significance. The content of serine, proline, alanine, tyrosine and cysteine was not significantly affected by the diet. Aspartic acid, glutamic acid, glycine, histidine and arginine content was significantly higher in E2 group compared to the control group $(P<0.5-P<0.01)$. The difference between E1 and E2 group was monitored only in aspartic acid, glutamic acid, histidine and arginine $(P<0.5-P<0.01)$. The highest content was measured for glutamic acid (from 11.633 to $12.715 \mathrm{~g} / 100 \mathrm{~g}$ ). The lowest proportion was found for cysteine; its content ranged from 1.109 to $1.188 \mathrm{~g} / 100 \mathrm{~g}$.
Table 4 Fatty acid profile and dietary indices

\begin{tabular}{|c|c|c|c|c|c|}
\hline \multirow[t]{2}{*}{ Fatty acid (\% of total FA) } & \multicolumn{5}{|c|}{ Feeding group } \\
\hline & $\mathrm{C}$ & E1 & E2 & SEM & $P<$ \\
\hline \multicolumn{6}{|l|}{$S F A^{1}$} \\
\hline Lauric (C12:0) & 0.424 & 0.421 & 0.386 & 0.029 & 0.839 \\
\hline Myristic (C14:0) & 1.316 & 1.186 & 1.136 & 0.041 & 0.183 \\
\hline Pentadecanoic (C15:0) & 0.367 & 0.313 & 0.348 & 0.017 & 0.422 \\
\hline Palmitic (C16:0) & 18.990 & 19.026 & 19.227 & 0.194 & 0.870 \\
\hline Margaric (C17:0) & 0.401 & 0.335 & 0.344 & 0.017 & 0.235 \\
\hline Stearic (C18:0) & 9.535 & 9.753 & 9.887 & 0.146 & 0.616 \\
\hline Total SFA & 44.022 & 43.630 & 43.302 & 0.365 & 0.369 \\
\hline \multicolumn{6}{|l|}{ MUFA ${ }^{2}$} \\
\hline Palmitoleic (C16:1n-7) & 3.222 & $2.844^{\mathrm{a}}$ & $3.279^{b}$ & 0.070 & 0.019 \\
\hline Oleic (C18:1n-9) & 33.712 & 34.265 & 35.216 & 0.386 & 0.278 \\
\hline C18:1n-7 & 3.470 & 3.321 & 3.575 & 0.050 & 0.115 \\
\hline Eicosenoic (C20:1n-9) & 0.669 & 0.674 & 0.661 & 0.011 & 0.892 \\
\hline Total MUFA & 43.251 & 42.957 & 44.577 & 0.411 & 0.233 \\
\hline \multicolumn{6}{|l|}{$P U F A^{3}$} \\
\hline Linoleic (C18:2n-6) & 7.731 & 8.784 & 7.573 & 0.241 & 0.081 \\
\hline Alpha-linolenic (C18:3n-3) & 0.601 & 0.720 & 0.581 & 0.035 & 0.228 \\
\hline Eikosadienoic (C20:2n-6) & 0.392 & 0.345 & 0.360 & 0.015 & 0.452 \\
\hline Eicosatrienoic (C20:3n-6) & 0.335 & 0.311 & 0.344 & 0.018 & 0.477 \\
\hline Arachidonic (C20:4n-6) & 1.358 & 1.314 & 1.514 & 0.046 & 0.182 \\
\hline EPA (C20:5n-3) & 0.484 & 0.402 & 0.379 & 0.025 & 0.196 \\
\hline $\mathrm{DHA}(\mathrm{C} 22: 6 n-3)$ & 0.509 & 0.366 & 0.452 & 0.027 & 0.098 \\
\hline Total PUFA & 12.727 & 13.413 & 12.121 & 0.284 & 0.395 \\
\hline \multicolumn{6}{|l|}{ Indices } \\
\hline Total PUFAn-6 & 10.657 & 11.423 & 10.527 & 0.253 & 0.299 \\
\hline Total PUFA n-3 & 1.930 & 1.798 & 1.757 & 0.075 & 0.619 \\
\hline PUFA n-6/PUFA n-3 & 6.352 & 6.812 & 6.221 & 0.305 & 0.714 \\
\hline $\mathrm{Al}^{4}$ & 0.444 & 0.432 & 0.427 & 0.007 & 0.622 \\
\hline $\mathrm{TI}^{5}$ & 0.768 & 0.764 & 0.777 & 0.011 & 0.893 \\
\hline SFA/USFA ${ }^{6}$ & 0.786 & 0.774 & 0.764 & 0.012 & 0.446 \\
\hline
\end{tabular}

(a-b) Row means with different superscripts differ significantly at $P<0.05$

${ }^{1}$ SFA saturated fatty acid, ${ }^{2}$ MUFA monounsaturated fatty acid, ${ }^{3} P U F A$

polyunsaturated fatty acid, ${ }^{4} \mathrm{~A} /$ atherogenic index, ${ }^{5} \mathrm{~T} /$ thrombogenic index, ${ }^{6}$ USFA unsaturated fatty acid

\section{Discussion}

The demand for raw materials rich in proteins for the production of forages is very high (e.g., in Poland it is approximately 1639 thousand tonnes of raw material rich in proteins). It is mainly satisfied by imported soya bean extraction meal (approximately 64\%). At the same time, attention is paid to the production of seeds of native hard-seeded legumes. The research conducted in this field indicates the possibility of replacing this protein raw material in mixed feeds without adversely affecting the efficiency of pork production and the quality of the obtained products. 
Table 5 Amino acid content in meat

\begin{tabular}{|c|c|c|c|c|c|}
\hline \multirow[t]{2}{*}{ Amino acid $(\mathrm{g} / 100 \mathrm{~g})$} & \multicolumn{5}{|c|}{ Feeding group } \\
\hline & $\mathrm{C}$ & E1 & E2 & SEM & $P<$ \\
\hline \multicolumn{6}{|l|}{ Essential } \\
\hline Threonine & $3.619^{\mathrm{a}}$ & 3.643 & $3.889^{b}$ & 0.044 & 0.023 \\
\hline Valine & $3.907^{\mathrm{a}}$ & 3.987 & $4.279^{b}$ & 0.056 & 0.019 \\
\hline Leucine & $6.246^{\mathrm{a}}$ & 6.284 & $6.705^{b}$ & 0.076 & 0.025 \\
\hline Isoleucine & $3.645^{\mathrm{a}}$ & 3.682 & $3.969^{b}$ & 0.049 & 0.015 \\
\hline Phenylalanine & $3.203^{\mathrm{a}}$ & 3.250 & $3.488^{b}$ & 0.047 & 0.033 \\
\hline Lysine & $6.887^{\mathrm{a}}$ & $6.904^{\mathrm{a}}$ & $7.468^{b}$ & 0.085 & 0.006 \\
\hline Methionine & 2.257 & 2.389 & 2.320 & 0.034 & 0.275 \\
\hline \multicolumn{6}{|l|}{ Nonessential } \\
\hline Aspartic acid & $7.177^{\mathrm{A}}$ & $7.360^{\mathrm{a}}$ & $7.893^{\mathrm{Bb}}$ & 0.085 & 0.002 \\
\hline Serine & 3.102 & 3.115 & 3.287 & 0.036 & 0.071 \\
\hline Glutamic acid & $11.633^{\mathrm{A}}$ & $11.674^{\mathrm{A}}$ & $12.715^{\mathrm{B}}$ & 0.140 & 0.001 \\
\hline Proline & 3.171 & 3.358 & 3.308 & 0.071 & 0.536 \\
\hline Glycine & $3.212^{\mathrm{a}}$ & 3.285 & $3.445^{b}$ & 0.036 & 0.030 \\
\hline Alanine & 4.352 & 4.357 & 4.617 & 0.051 & 0.059 \\
\hline Tyrosine & 3.106 & 3.065 & 3.424 & 0.099 & 0.286 \\
\hline Histidine & $3.482^{\mathrm{A}}$ & $3.549^{\mathrm{a}}$ & $3.814^{\mathrm{Bb}}$ & 0.044 & 0.006 \\
\hline Arginine & $4.902^{\mathrm{A}}$ & $4.959^{A}$ & $5.439^{B}$ & 0.067 & 0.001 \\
\hline Cysteine & 1.109 & 1.172 & 1.188 & 0.026 & 0.453 \\
\hline
\end{tabular}

(A-B) Row means with different superscripts differ significantly at $P<0.01$

${ }^{(a-b)}$ Row means with different superscripts differ significantly at $P<0.05$

The results of numerous studies on the effect of feeding fattening pigs with a feed mixture with a different proportion of legumes did not show any significant differences in the characteristics of meat quality $[8,13,14$, 17-20]. Moreover, the values of individual physicochemical characteristics indicate that the meat obtained after the application of a diet rich in seeds of legumes grown in Poland is good quality [13, 21-23]. Which was also confirmed in this study. The studies by Milczarek and Osek [22] showed a beneficial effect of replacing soya bean seeds in the diet of pigs by $10 \%$ and $20 \%$ low-tannin field beans on the content of free water (WHC) in meat, which grew by over $2 \%$. In turn, Sońta et al. [23] demonstrated that partial replacement of soya bean extraction meal with $7.5 \%$ yellow lupin resulted in a significantly higher (by 1\%) drip loss of meat. The situation regarding the loss of meat juice in this study was different, in which no statistically significant differences were noted between the groups fed with a different proportion of peas and lupines in diet. The other hand, Milczarek and Osek [24] obtained a lower drip loss in the meat of Puławy breed fattening a diet with the addition of $10 \%$ low-tannin field bean seeds than in the meat of pigs fed with a mixed feed containing soya bean extraction meal.

The research conducted in Poland and abroad, and also the results presented above, they did not show a negative impact of replacing soya beans in a complete feed mixture with legumes on the level of total protein and intramuscular fat in pork [13, 14, 23, 25, 26]. The lower content of total protein in meat (about 2\%) compared to the results obtained in this study was obtained in the studies by Chrenková et al. [14], who used a mixture with a $30 \%$ addition of peas in the diet of pigs, and Zraly. et al. [20] who used a 10\% addition of lupin. Mordenti et al. [10] also obtained a lower protein content $(21.05 \%)$ in the meat of pigs fed the mixture with the addition of field beans. On the other hand, a higher intramuscular fat content in meat, by $1 \%$, was obtained in the studies by Bocian et al. [13], Chrenková et al. [14], Zralỳ et al. [20]. Fiedorowicz-Szatkowska et al. [27] showed a lower content of intramuscular fat in the meat of pigs fed with the addition of peas, compared to meat obtained from fattening pigs fed with a mixed feed based on soya beans as the main source of protein. The results described above, however, were not reflected in own research, in which the content of intramuscular fat was similar in all the studied groups of pigs.

One of the important parameters for assessing the quality of meat is its colour, as it determines the preferences of consumers during its purchase. The results of visual, tactile, and instrumental evaluation of meat, its colour and muscle pigments (Table 2) are similar to those obtained by Bocian et al. [13]. These authors showed no significant differences in the assessed characteristics between the meat samples obtained from pigs fed with a mixture based on soya beans (control group), and a diet with $20 \%$ addition of peas and $37.6 \%$ addition of lupin in the first stage of fattening as well as $38.5 \%$ addition of peas and $20 \%$ addition of lupin in the second phase (experimental group). Stein et al. [28] also showed that meat obtained from pigs fed a diet with an increased content of peas $(66 \%)$ was darker and with a more desirable colour (3.22 points) in comparison with pigs fed with forages containing soya bean extraction meal (2.41 points). In this study, the brightness $\mathrm{L}^{*}$ of meat colour in the studied groups of pigs was at a similar level (56.07-56.95). The obtained $L^{*}$ values indicate meat with a lighter colour than the values indicated in the studies performed by Milczarek and Osek [22], Sońta et al. [23], Hanczakowska and Światkiewicz [15], where in the meat of pigs fed a diet with a varied content of legumes, a darker colour ( $L^{*}$ 49-52) was observed. Probably the light color of meat was a result of participation of Pietrain breed in hybrids used in this research. Grabež et al. [29] demonstrated that meat obtained from fattening pigs fed fodder containing rapeseed and field bean seeds as the main source of protein was characterised by a darker, more desirable colour and a much lower proportion of yellow. 
The content of minerals in pork determines its nutritional value. The applied feeding of pigs with a diet with a different proportion of legumes did not adversely affect the content of minerals in the meat (Table 3). In the study by Milczarek and Osek [24] concerning the meat of Puławy breed pigs fed a mixture with $10 \%$ of low-tannin field beans, the obtained amounts of mineral compounds of $\mathrm{P}, \mathrm{K}, \mathrm{Ca}, \mathrm{Na}, \mathrm{Zn}$ and $\mathrm{Mn}$ were similar; the amount of $\mathrm{Cu}$ was higher $\left(0.088-0.104 \mathrm{mg}^{*} 100 \mathrm{~g}^{-1}\right)$, while the amount of Fe was lower $\left(0.89-1.02 \mathrm{mg}^{*} 100 \mathrm{~g}^{-1}\right)$ in comparison to the present study (Table 3). In turn, Stasiak et al. [26] analysed the meat of pigs fed a mixture with $35 \%$ addition of lupin and $5 \%$ addition of peas, and demonstrated a higher content of $\mathrm{Mg}\left(282,34 \mathrm{mg}^{*} \mathrm{~kg}^{-1}\right)$ but a lower content of $\mathrm{K}, \mathrm{Na}$ and $\mathrm{Fe}$ (appropriately 3668.41; $329.35 ; 0.02 \mathrm{mg}^{*} \mathrm{~kg}^{-1}$ ) in comparison to those obtained in this study. Hanczakowska et al. [30] studied the possibility to replace a part of soybean in pig diet by 4 different varieties of lupine. During the fattening period they did not observe significant differences in weight gain. Meat from pigs fed a diet of lupin was poorer in n-3 PUFA than the meat from the control group. The content of palmitic and palmitoleic acid was significantly higher in the experimental groups and the content of stearic and alpha-linolenic acid was significantly lower. According Petterson [31] the feeding of lupin seeds to pigs is associated with alteration of the fatty acid profile in backfat. The author states that L. luteus contains $21 \%$ of oleic acid, $47 \%$ of linoleic acid, and the content of these fatty acids in fat corresponds with this finding. Also, Rybiński et al. [32] mentioned the lupin seed oil as a rich source of unsaturated fatty acids such as oleic acids. The n-6/n-3 PUFA ranges from 1:1.7 to 1:10.8 [33]. Zralý et al. [19] studied the use of white lupin in pig diet and its effect on pork quality. According authors, the lupin diet was characterised by higher content of oleic acid compared to control diet. The content of linoleic, linolenic acid, SFA and PUFA was lower in the experimental diet. But the results were not statistically significant. The same tendency was observed in our experiment. Prandini et al. [34] studied the effect of pea and faba bean seeds as a protein source in growing-finishing pig diets. Dietary treatment affected linoleic acid level, n-6 PUFA content, total MUFA and total PUFA content in the subcutaneous fat of pigs. Trombetta et al. [35] also found a low effect of the pea on the fatty acid profile of intramuscular fat. Písaříková and Zralý [36] and Písař́íková et al. [37] marked the lupin seeds as a source of protein in pig diet which is characterised by lower concentration of lysine, methionine, cysteine, threonine, valine and tryptophan in comparison with other protein sources as soybean meal, fish meal or meat and bone meals. The lower availability of lysin was suggested as a problem of lupin seeds in pig diet [38] but in recent varieties the availability of lysine was improved [18].

\section{Conclusions}

Replacing soya bean protein in pigs' diet, even in 100\% in the second stage of fattening, with legume protein (peas and yellow lupins) did not adversely affect meat quality. It should be emphasised that the obtained results of the physicochemical characteristics of the meat indicated its good quality. Moreover, meat contained a high content of total protein (approx. 25\%) in its composition, and thus was characterised by a high nutritional value. Moreover, in the meat of pigs fed with an increased share of pea and lupine in the ration, more favourable proportion of essential amino acids was observed.

\section{Methods}

\section{Animals and sampling}

The experiment was carried out on meat obtained from 60 fattening crossbred pigs $\mathrm{F}_{1}$ (Polish Large White $\times$ Polish Landrace) $\times F_{1}$ (Pietrain $\times$ Duroc), which originated from and were raised on the same farm, under the same environmental conditions, in accordance with the welfare requirements. The animals were marked and placed in identical pens equipped with an auto-feeder and automatic nipple drinker, allowing for constant access to water. The study did not require the approval of the ethics committee. They were part of the production cycle and their main purpose was to assess the quality of meat (Directive 2010/63/EU).

The animals were divided into three feeding groups, each comprising 20 animals $(50 \%$ of gilts and $50 \%$ of barrows). Fattening pigs were fed ad libitum with complete feed mixtures, differing in the source of protein origin: control group $\mathrm{C}$ : in the 1st and 2nd fattening phase, standard nutrition with $100 \%$ of soya bean extraction meal was used; experimental group E1: in the 1st phase of fattening, the soya bean protein was replaced in 50\% with the pea and lupin protein and in the 2nd phase the soya bean protein was replaced in $75 \%$ with the pea and lupin protein; experimental group E2: in the 1st phase the soya bean protein was replaced in $50 \%$ with the pea and lupin protein, and in the 2 nd phase the soya bean was completely eliminated (100\% pea and lupin protein). The composition and nutritional value of the complete feed mixture are provided in Tables 6 and 7 .

Animals mean body weight at the beginning of fattening was $31.60 \pm 3.01 \mathrm{~kg}$. The duration of the fattening period was $87.69 \pm 7.07$ days. After the fattening was complete, the animals were individually weighed and then transported to a slaughterhouse situated approximately $20 \mathrm{~km}$ distant. The mean body weight of fattening pigs at slaughter was $112.66 \pm 2.75 \mathrm{~kg}$. The animals were 
Table 6 Dietary value and composition of the fodder

\begin{tabular}{|c|c|c|c|c|c|c|}
\hline \multirow[t]{2}{*}{ Dietary value } & \multicolumn{2}{|l|}{ Control } & \multicolumn{2}{|l|}{ E1 } & \multicolumn{2}{|l|}{ E2 } \\
\hline & $\begin{array}{l}\text { Phase I } \\
(30-70 \mathrm{~kg})\end{array}$ & $\begin{array}{l}\text { Phase II } \\
(70-115 \mathrm{~kg})\end{array}$ & $\begin{array}{l}\text { Phase I } \\
(30-70 \mathrm{~kg})\end{array}$ & $\begin{array}{l}\text { Phase II } \\
(70-115 \mathrm{~kg})\end{array}$ & $\begin{array}{l}\text { Phase I } \\
(30-70 \mathrm{~kg})\end{array}$ & $\begin{array}{l}\text { Phase II } \\
(70-115 \mathrm{~kg})\end{array}$ \\
\hline \multicolumn{7}{|l|}{ Composition of the fodder, $\%$} \\
\hline Soy meal $46 \%$ total protein & 16 & 12 & 10 & 4 & 10 & - \\
\hline Wheat $12 \%$ & 20 & 20 & 20 & 20 & 20 & 20 \\
\hline Barley $12 \%$ & 35 & 45 & 30 & 41 & 30 & 35 \\
\hline Triticale $10 \%$ & 25.3 & 20 & 26 & 20 & 26 & 20 \\
\hline Soybean oil & 1 & 0.3 & 1.3 & 0.3 & 1.3 & 0.3 \\
\hline Lupin 37\% & - & - & 7 & 9 & 7 & 12 \\
\hline Pea 21\% & - & - & 3 & 3 & 3 & 10 \\
\hline PORKOVITAL T PEA 2.5\% & 2.5 & 2.5 & 2.5 & 2.5 & 2.5 & 2.5 \\
\hline SELACID GG DRY 25 BR & 0.2 & 0.2 & 0.2 & 0.2 & 0.2 & 0.2 \\
\hline Total & 100 & 100 & 100 & 100 & 100 & 100 \\
\hline Dry matter, $\mathrm{g}$ & 877 & 875 & 877 & 875 & 877 & 875 \\
\hline Metabolic energy, MJ & 13.39 & 13.11 & 13.32 & 13.09 & 13.32 & 13.12 \\
\hline Total protein, g & 170 & 159 & 171 & 157 & 171 & 160 \\
\hline Fat, $g$ & 27 & 20 & 29 & 20 & 29 & 20 \\
\hline Lysine, $\mathrm{g}$ & 10.6 & 9.7 & 10.6 & 9.7 & 10.6 & 9.7 \\
\hline Calcium, g & 5.9 & 5.8 & 5.9 & 5.8 & 5.9 & 5.8 \\
\hline Phosphorus, g & 5.3 & 5.2 & 5.3 & 5.2 & 5.3 & 5.2 \\
\hline Sodium, $g$ & 1.7 & 1.7 & 1.7 & 1.7 & 1.7 & 1.7 \\
\hline Vitamin A, IU & 10,000 & 10,000 & 10,000 & 10,000 & 10,000 & 10,000 \\
\hline Vitamin D, IU & 2200 & 2200 & 2200 & 2200 & 2200 & 2200 \\
\hline Vitamin E, IU & 80 & 80 & 80 & 80 & 80 & 80 \\
\hline
\end{tabular}

slaughtered in meat processing plants using the electrical stunning method.

\section{Meat analysis}

The acidity of the meat was determined $45 \mathrm{~min}$ after slaughter $\left(\mathrm{pH}_{45}\right)$ and $48 \mathrm{~h}$ after slaughter $\left(\mathrm{pH}_{\mathrm{u}}\right)$ using an pH-meter with a blade electrode (Elmetron CP 401). The device was calibrated with $\mathrm{pH} 7.0$ and $\mathrm{pH} 4.0$ buffers provided by Elmetron. Meat quality was assessed $48 \mathrm{~h}$ after slaughter on samples of the longissimus lumborum muscle, which were stored under refrigeration at $4-6{ }^{\circ} \mathrm{C}$.

Water holding capacity (WHC) was determined using the method developed by Grau and Hamm [39] as modified by Pohja and Niinivaar [40]. A $300 \mathrm{mg}$ sample of ground meat was applied to a Whatman 1 type filter paper, placed between two glass plates and subjected to a uniformly distributed load of $2 \mathrm{~kg}$ for $5 \mathrm{~min}$. The percentage of free water in the meat was calculated based on the drip surface area, assuming that $1 \mathrm{~cm}^{2}$ of the drip corresponds to $10 \mathrm{mg}$ of water [11]. The drip surface area of the meat juice was measured using the LUCIA image analysis software (System for Image Processing and Analysis, version 4.82.2004). Thermal drip was determined $48 \mathrm{~h}$ after slaughter using the Walczak method [41]. A sample of ground meat $(20 \mathrm{~g})$ was placed in hygroscopic gauze and heated in a water bath at $85{ }^{\circ} \mathrm{C}$ for $10 \mathrm{~min}$. After the removal of the sample and the gas, the sample was cooled down to $4{ }^{\circ} \mathrm{C}$ and weighed. Percentage loss was calculated based on the difference in meat weight before and after heat treatment.

Tenderness was measured using the INSTRON 3342 universal testing machine with a Warner-Bratzler Shear Force (WBSF) in accordance with the methodology provided by Szalata et al. [42]. A sample of meat weighing approximately $120 \mathrm{~g}$ was heated in a water bath until the temperature inside the bath reached $70{ }^{\circ} \mathrm{C}$. Heat treatment was carried out in a $\mathrm{NaCl}$ solution with a concentration of $0.85 \%$. Subsequently, $10 \mathrm{~mm} \times 10 \mathrm{~mm}$ bars were cut out in accordance with the course of the muscle fibres, and they were cut perpendicularly to their course. The results were read in the form of the maximum shear force, expressed in $\mathrm{N}$.

Chemical composition of meat, i.e., the content of water, protein and fat, was determined in accordance with the Polish standard [43] by the method of nearinfrared transmission (NIT) spectrometry using calibration on artificial neural networks (ANN) performed by the FoodScan (device provided by FOSS). 
Table 7 Composition of the concentrate

\begin{tabular}{|c|c|}
\hline PORKOVITAL T PEA $2.5 \%$ & \\
\hline \multicolumn{2}{|l|}{ Składnikw $1 \mathrm{~kg}$} \\
\hline Lizyna g & 120 \\
\hline Metionina g & 40 \\
\hline Treonina g & 50 \\
\hline Tryptofan g & 3 \\
\hline Wapń ogólny g & 205 \\
\hline Fosfor ogólny g & 80 \\
\hline sód g & 64 \\
\hline Witamina $\mathrm{E}+\mathrm{AO}-\mathrm{mix} \mathrm{IU}$ & 3200 \\
\hline Witamina A IU & 260000 \\
\hline DIU & 80000 \\
\hline $\mathrm{Kmg}$ & 80 \\
\hline $\mathrm{Cmg}$ & - \\
\hline B1 mg & 60 \\
\hline B2 mg & 200 \\
\hline B6 mg & 88 \\
\hline Niacyna mg & 1200 \\
\hline Kwas foliowy mg & 32 \\
\hline Pantotenian wapnia mg & 640 \\
\hline Cholina mg & 9217 \\
\hline Biotyna mcg & 2400 \\
\hline Witamina B12 mcg & 1600 \\
\hline Żelazo mg & 4800 \\
\hline Mangan mg & 2400 \\
\hline Cynkmg & 4800 \\
\hline miedź mg & 1000 \\
\hline Jod mg & 44 \\
\hline selen mg & 12 \\
\hline
\end{tabular}

Visual and tactile evaluation was conducted $48 \mathrm{~h}$ after slaughter on a $120 \mathrm{~g}$ slice of raw meat. Visual and tactile evaluation of the meat was carried out by a 10-person trained team. All evaluators had 4 years of experience in evaluating pork. The following elements were determined visually in raw meat: visual colour intensity according to a 6-point scale [44]: 1 point-very light meat, 6-dark purple meat; marbling with the use of Canadian and American standards on a 10-point scale [45, 46]: 1 -meat without overgrowth, 10-very high marbling score, and tactile evaluation: firmness on a 7-point scale [44]: 1very hard, 7-very soft.

Meat colour was also measured on a slice of raw meat, $48 \mathrm{~h}$ after slaughter, using a Minolta CR 310 photo colorimeter (Konica Minolta, Japan) with a measuring port diameter of $50 \mathrm{~mm}$. The device was standardised using a white CR310 standard plate with the following coordinates: $Y=92.80, x=0.3175$ and $y=0.3333$ Colour parameters were determined in the CIE L"a*b* system $\left(\mathrm{L}^{*}\right.$-lightness, $\mathrm{a}^{*}-$ value representing redness, $\mathrm{b}^{*}$-represents yellowness) [47], with the use of a D65 illuminant and a $2^{\circ}$ standard observer. Chroma $\left(\mathrm{C}^{*}\right)$ and hue angle $\left(\mathrm{h}^{\circ}\right)$ were calculated according to Beattie et al. [48] and Brewer et al. [49]:

$$
C *=\sqrt{a *^{2}+b *^{2}}, h^{\circ}=\tan ^{-1} \frac{b *}{a *}
$$

Muscle pigments were determined colourimetrically according to the Hornsey method [50]. Ground meat samples $(10 \mathrm{~g})$ were covered with $40 \mathrm{ml}$ of acetone: water: concentrated $\mathrm{HCl}$ mixture at a ratio of $40: 2: 1$ and extracted for $1 \mathrm{~h}$. After filtration, the absorbance of the test solutions was measured with a Marcel Media spectrophotometer at a wavelength of $640 \mathrm{~nm}$. The optical density value (E) was multiplied by a factor of 680 to obtain the correct hematin concentration expressed as micrograms of hematin per $1 \mathrm{~g}$ of meat.

The content of minerals in the meat was determined by atomic absorption spectrometry (Solaar 969 device) [51, 52]. For this purpose, freeze-dried meat samples, subjected to wet mineralisation (Ethos Plus microwave mineraliser), were used.

Fatty acid composition of meat was determined after chloroform methanol extraction of total lipids [53]. Fatty acid methyl esters were prepared in accordance with CSN ISO 5509 [54] and analysed by gas chromatography (gas chromatograph $6890 \mathrm{~N}$ Agilent Technologies) according to CSN ISO 5508 [55]. The gas chromatograph was equipped with DB-23 cyanopropylmethylpolysiloxane column (150 to $230{ }^{\circ} \mathrm{C}$ ). Fatty acids were determined by comparison with standards (37 Component FAME Mix, PUFA No. 1, PUFA No. 2, PUFA No. 3; Sigma-Aldrich). Results were expressed as percentages of the total fatty acid.

The atherogenic index (AI) and thrombogenic index (TI) were calculated in accordance with Ulbricht and Southgate [56]:

$$
\begin{aligned}
& A I=\frac{C 12: 0+4 C 14: 0+C 16: 0}{\sum M U F A+\sum(n-6)+\sum(n-3)} \\
& T I=\frac{C 14: 0+C 16: 0+C 18: 0}{0.5 \sum M U F A+0.5 \sum(n-6)+3 \sum(n-3)+\frac{\sum(n-3)}{\sum(n-6)}}
\end{aligned}
$$

The representative samples of meat were homogenised and subjected to chemical analyses to determine selected amino acids using an Amino Acid Analyser AAA 400 (INGOS Ltd., Prague, Czech Republic, evaluation by the ChromuLan programme) equipped with an ion-exchange column. Amino acids were released from the protein molecules by acid hydrolysis with $6 \mathrm{M}$ hydrochloric acid. 


\section{Statistical analysis}

The meat quality results met the assumptions of normal distribution. It was verified by the Shapiro-Wilk test. The arithmetic mean and standard deviation for the characteristics of the slaughter value and the standard error of the mean (SEM) for the meat quality characteristics were calculated. The significance of differences between C, E1 and E2 feeding groups was calculated using the Tukey's HSD test for equal group sizes. A probability $P<0.05$ was considered statistically significant. All calculations were performed using Statistica 13.3 PL software [57].

\section{Authors' contributions}

Conceptualization AC, HJ. Methodology AC, HJ, EW. Investigation AC, HJ. Statistical analysis AC, HJ. Resources PN. Writing-original draft preparation AC, HJ. Writing - review and editing AC, HJ, EW, PN. All authors read and approved the final manuscript.

\section{Funding}

This study was realised from statutory research funds BS-12/2018 assigned by the Polish Ministry of Science and Higher Education.

\section{Availability of data and materials}

All data generated or analysed during this study are included in this published article.

\section{Declarations}

Ethics approval and consent to participate

Not applicable.

\section{Consent for publication}

Not applicable.

\section{Competing interests}

The authors declare that they have no competing interests.

\section{Author details}

'Department of Animal Breeding and Nutrition, Faculty of Animal Breeding and Biology, UTP-University of Science and Technology in Bydgoszcz, Mazowiecka 28, 85-084 Bydgoszcz, Poland. ${ }^{2}$ Institute of Animal Science, Prague-Uhříněves, Komenského 1239, Kostelec nad Orlicí 517 41, Czech Republic. ${ }^{3}$ Departament of Animal Breeding, Faculty of AgriSciences, Mendel University in Brno, Zemědělská 1, 61300 Brno, Czech Republic.

Received: 14 July 2021 Accepted: 3 December 2021

Published online: 19 December 2021

\section{References}

1. Pettigrew JE, Esnaola MA. Swine nutrition and pork quality: a review. J Anim Sci. 2001. https://doi.org/10.2527/jas2001.79E-SupplE316x.

2. Rosenfold K, Andersen HJ. Factors of significance for pork quality-a review. Meat Sci. 2003. https://doi.org/10.1016/S0309-1740(02)00186-9.

3. Cisneros F, Ellis M, Baker DH, Easter RA, McKeith FK. The influence of shortterm feeding of amino acid-deficient diets and high dietary leucine levels on the intramuscular fat content of pig muscle. Anim Sci. 1996;63:517-52.

4. Sonta M, Rekiel A, Wiecek J, Batorska M, Puppel K. Alternative protein sources vs. GM soybean meal as feedstuff for pigs-meat quality and health-promoting indicators. Animals. 2021. https://doi.org/10.3390/ ani1 1010177
5. Specht JE, Hume DJ, Kumudini SV. Soybean yield potential - a genetic and physiological perspective. Crop Sci. 1999. https://doi.org/10.2135/ cropsci1999.3961560x

6. Lucht JM. Public acceptance of plant biotechnology and GM crops. Viruses. 2015;7(8):4254-81.

7. Woźniak E, Twardowski T. GMO-is it possible to breed livestock without GM feed in Poland? Nauka. 2018;3:155-73.

8. Mordenti AL, Martelli G, Brogna N, Nannoni E, Vignola G, Zaghini G, Sardi L. Effects of soybean-free diet supplied to Italian heavy pigs on fattening performance, and meat and dry-cured ham quality. Italian J Anim Sci. 2012. https://doi.org/10.4081/ijas.2012.e80.

9. Kasprowicz-Potocka M, Zaworska A, Kołata T, Grajewski J, Twarużek M, Rutkowski A. Wyniki wieloletniego monitoringu wartości pokarmowej krajowych pasz wysokobiałkowych pochodzenia roślinnego. In: Rutkowski A, editor. Zalecenia żywieniowe dotyczące stosowania krajowych pasz wysokobiałkowych pochodzenia roślinnego dla świń i drobiu. Bydgoszcz: APRA sp. z o.o; 2017. p. 9-25.

10. Kim JC, Pluske JR, Mullan BP. Nutritive value of yellow lupins (Lupinus luteus L.) for weaner pigs. Aust J Exp Agric. 2008;48:1225-31.

11. Jankowiak H, Bocian M, Barczak J. The effect of intramuscular fat content on the meat quality of PLW X PL pigs. Ital J Food Sci. 2019;31:87-97.

12. Chang SY, Belal SA, Kang DR, Choi Yl, Kim YH, Choe HS, Heo JY, Shim HS. Influence of probiotics-friendly pig production on meat quality and physiochemical Characteristics. Korean J Food Sci Anim Resour. 2018. https://doi.org/10.5851/kosfa.2018.38.2.403.

13. Bocian M, Kapelański W, Adamowicz M, Jankowiak H, Cebulska A, Gimińska A, Mońko A. Influence of nutrition of pigs with legumeenriched mixtures on the quality of pork. Sci Nat Technol. 2016. https:// doi.org/10.17306/J.NPT.2016.4.46.

14. Chrenková M, Formelová Z, Chrastinová L’, Flak P, Čerešňáková Z, Lahučký R, Poláčiková M, Bahelka I. Influence of diets containing raw or extruded peas instead of soybean meal on meat quality characteristics in growingfinishing pigs. Czech J Anim Sci. 2011;56:119-26.

15. Hanczakowska E, Świątkiewicz M. Legume seeds and rapeseed press cake as replacers of soybean meal In feed for fattening pigs. Ann Anim Sci. 2014. https://doi.org/10.2478/aoas-2014-0068.

16. Zmudzinska A, Bigorowski B, Banaszak M, Roślewska A, Adamski M, Hejdysz M. The effect of diet based on legume seeds and rapeseed meal on pig performance and meat quality. Animals. 2020. https://doi.org/10. 3390/ani10061084.

17. Kim JC, Mullan BP, Nicholls RR, Pluske JR. Effect of Australian sweet lupin (Lupinus angustifolius L.) inclusion levels and enzyme supplementation on the performance, carcass composition and meat quality of grower/ finisher pigs. Anim Prod Sci. 2011;51:37-43.

18. Kim JC, Pluske JR, Mullan BP. Lupins as a protein source in pig diets CAB Reviews: Perspectives in Agriculture, Veterinary Science, Nutrition and Natural Resources 2. 2007; doi:https://doi.org/10.1079/pavsnnr20072003.

19. Zralý Z, Pisařikova B, Trčkova M, Herzig I, Jůzl M, Simeonovova J. The effect of white lupine on the performance, health, carcass characteristics and meat quality of market pigs. Vet Med. 2007;52:29-41.

20. Zralý Z, Písaříková B, Trčková $M$, Herzig I, Jůzl M, Simeonovová J. Effect of Lupine and amaranth on growth efficiency, health, and carcass characteristics and meat quality of market pigs. Acta Vet Brno. 2006. https://doi. org/10.2754/avb200675030363.

21. Bocian M, Jankowiak H, Kapelański W. Changes of meat colour during storage. Sci Nat Technol. 2015. https://doi.org/10.17306/J.NPT.2015.4.57.

22. Milczarek A, Osek M. Meat quality in pigs fed mixtures with low-tanin faba bean. Ann Warsaw Univ of Life Sci - SGGW. 2017; https://doi.org/10. 22630/AAS.2017.56.1.12.

23. Sońta M, Rekiel A, Więcek J, Kuczyńska B, Kniżewska W. Meat quality of fattening pigs fed yellow lupin-based diets. Ann Warsaw Univ of Life SciSGGW. 2017:56:121-127

24. Milczarek A, Osek M. Meat quality of Pulawska breed pigs fed mixtures with low-tannin faba bean meal. Food Sci Technol Qual. 2016;1:57-67.

25. Zralý Z, Pisařikova B, Trčkova M, Doležal M, Thiemel J, Simeonovova J, Jůzl M. Replacement of soya in pig diets with white lupine cv. Butan Czech J Anim Sci. 2008;53(10):418-30.

26. Stasiak K, Roślewska A, Stanek M, Cygan-Szczegielniak D, Janicki B. The content of selected minerals determined in the liver, kidney and meat of pigs. J Elem. 2017. https://doi.org/10.5601/jelem.2017.22.1.1314. 
27. Fiedorowicz-Szatkowska E, Sobotka W, Stanek M. Fattening performance and the nutritional value of meat from finishing pigs fed diets containing different sources of vegetable. J Elem. 2017. https://doi.org/10.5601/ jelem.2017.22.1.1305.

28. Stein HH, Everts AKR, Sweeter KK, Peters DN, Maddock RJ, Wulf DM, Pedersen C. The influence of dietary field peas (Pisum sativum L.) on pig performance, carcass quality, and the palatability of pork. J Anim Sci. 2006. https://doi.org/10.2527/jas.2005-744.

29. Grabež V, Egelandsdal B, Kjos NP, Håkenåsen IM, Mydland LT, Vik JO, Hallenstvedt E, Devle H, Øverland M. Replacing soybean meal with rapeseed meal and faba beans in a growing-finishing pig diet: Effect on growth performance, meat quality and metabolite changes. Meat Sci. 2020. https://doi.org/10.1016/j.meatsci.2020.108134.

30. Hanczakowska E, Ksiezak J, Swiatkiewicz M. Efficiency of lupine seed (Lupinus angustifolium and Lupinus luteus) in sow, piglet and fattener feeding. Agric Food Sci. 2017;26:1-15.

31. Petterson DS. The use of lupines in feeding systems. Asian-Australas J Anim Sci. 2000;13:861-82.

32. Rybiński W, Święcicki W, Bocianowski J, Börner A, Starzycka-Korbas E, Starzycki M. Variability of fat content and fatty acids profiles in seeds of a Polish white lupin (Lupinus albus L.) collection. Genet Resour Crop Evol. 2018;65:417-31.

33. Sedláková K, Straková E, Suchý P, Krejcarová J, Herzig I. Lupin as a perspective protein plant for animal and human nutrition-a review. Acta Vet Brno. 2016. https://doi.org/10.2754/avb201685020165.

34. Prandini A, Sigolo S, Morlacchini M, Cerioli C, Masoero F. Pea (Pisum sativum) and faba bean (Vicia faba L.) seeds as protein sources in growing-finishing heavy pig diets: effect on growth performance, carcass characteristics and on fresh and seasoned Parma ham quality. Ital J Anim Sci. 2011. https://doi.org/10.4081/ijas.2011.e45.

35. Trombetta MF, Mattii S, Pasquini M, Falaschini A. Influence of diet and rearing system on heavy pig performance, carcass and meat quality. Ital J Anim Sci. 2009. https://doi.org/10.4081/ijas.2009.23.

36. Písaříková B, Zralý Z. Nutritional Value of Lupine in the Diets for Pigs (a Review) Acta Vet Brno. 2009. https://doi.org/10.2754/avb200978030399.

37. Písaříková B, Zralý Z, Buňka F, Trčková M. Nutritional value of white lupine cultivar Butan in diets for fattening pigs. Vet Med. 2008;53:124-34.

38. Batterham ES, Murison RD, Andersen LM. Availability of lysine in vegetable protein concentrates as determined by the slope-ratio assay with growing pigs and rats any by chemical techniques. Br J Nutr. 1984;51:85-99.

39. Grau R, Hamm R. Eine einfache Methode zur Bestimmung der Wasserbindung im Fleisch. Fleischwirtschaft. 1952;4:295-7.

40. Pohja MS, Niinivaara FP. Die bestimmung der Wasserbindung des Fleisches mittels der Konstantdrückmethode. Fleischwirtschaft. 1957;9:193-5.

41. Walczak Z. Laboratory method for determining the content of jelly in meat preserves. Ann Agric Sci. 1959;7:619-21.

42. Szalata M, Pospiech E, Łyczyński A, Urbaniak M, Frankiewicz A, Mikołajczak B, Mesyński A, Rzosińska E, Bartkowiak Z, Danyluk B. Kruchość mięsa świń o zróżnicowanej mięsności. Roczniki Instytutu Przemysłu Mięsnego i Tłuszczowego. 1999;36:61-7.

43. PN-A-82109:2010 Meat and meat products. Determination of fat, protein and water content - Near Infrared Transmission Spectrometry (NIT) with Artificial Neural Network Calibration. The Polish Committee for Standardization. 2010

44. PN-ISO 4121:1998. Sensory analysis. Methodology. Evaluation of food products by methods using scales. The Polish Committee for Standardization. 1998.

45. Cheng W, Cheng JH, Sun SW, Pu H. Marbling analysis for evaluating meat quality: methods and techniques. Compr Rev Food Sci F. 2015;14(5):523-35.

46. NPPC (National Pork Producers Council). NPPC marbling standars. USA Des Moines. 1999.

47. CIE. Colorimetry. Publication CIE 15.2. Vienna: Central Bureau of CIE. 1986.

48. Beattie VE, Weatherup RN, Moss BW, Walker N. The effect of increasing carcass weight of finishing boars and gilts on joint composition and meat quality. Meat Sci. 1999;52:205-11.

49. Brewer MS, Zhu LG, Bidner B, Meisinger DJ, McKeith FK. Measuring pork color: effects of bloom time, muscle, $\mathrm{pH}$ and relationship to instrumental parameters. Meat Sci. 2001;57:169-76.
50. Hornsey HC. The colour of cooked cured pork. I. Estimation of the nitric oxide-haem pigments. J Sci Food Agric. 1956;7:534-40.

51. PN-EN 14084:2004. Food products. Determination of trace elements. Determination of lead, cadmium, zinc, copper and iron by flame atomic absorption spectrometry (AAS) after microwave mineralization. The Polish Committee for Standardization. 2004.

52. PN-EN 15505:2009. Food products. Determination of trace elements. Determination of sodium and magnesium content by flame atomic absorption spectrometry (AAS) after microwave mineralization. The Polish Committee for Standardization. 2009.

53. Folch J, Lees M, Stanley SGH. A simple method for the isolation and purification of total lipids from animal tissues. J Biol Chem. 1957;226:497-509.

54. CSN ISO 5509. Animal and vegetable fats and oils. Preparation of methyl esters of fatty acids. The Czech Office for Standards, Metrology and Testing Prague, Czech Republic. 1994.

55. ČSN ISO 5508. Animal and vegetable fats and oils. Analysis by gas chromatography of methyl esters of fatty acids. The Czech Office for Standards, Metrology and Testing Prague, Czech Republic. 1994.

56. Ulbricht TLV, Southgate DAT. Coronary heart disease: seven dietary factors. Lancet. 1991;338:985-92.

57. STATISTICA. StatSoft, Inc. (data analysis software system), version 13.3. wWw. Statsoft.com. 2019.

\section{Publisher's Note}

Springer Nature remains neutral with regard to jurisdictional claims in published maps and institutional affiliations.

Ready to submit your research? Choose BMC and benefit from:

- fast, convenient online submission

- thorough peer review by experienced researchers in your field

- rapid publication on acceptance

- support for research data, including large and complex data types

- gold Open Access which fosters wider collaboration and increased citations

- maximum visibility for your research: over 100M website views per year

At BMC, research is always in progress.

Learn more biomedcentral.com/submissions 